抄 録

順天堂医学. 2005, 51 P. $218 \sim 219$

\section{平成16年度順天堂大学研究基盤センター 超微形態研究部門研究報告会抄録*}

\section{ラット低酸素・再酸素化モデル心におけるギャップ結 合タンパクの脱リン酸化のジルチアゼムによる抑制効 果の形態学的検討}

松下 訓 ${ }^{1,2}$ 栗原，秀剛 ${ }^{1}$ 坂井 建雄 ${ }^{1}$

天野 篤 ${ }^{2}$ 渡邊又キノ 3 岡田 $\quad$ 隆夫 ${ }^{3}$

1 解剖学第一 2 心臟血管外科学 3 生理学第二

細胞間の伝達機構であるギャップ結合は主にコネキ シン $43(\mathrm{Cx} 43)$ と呼ばれるタンパクで構成されている. 近年の研究でギャップ結合は $\mathrm{Cx} 43$ のリン酸化状態の 変化によって，その形態や機能を変化させることが報 告されている，今回われわれはラットの心臓を摘出し ランゲンドルフ灌流として低酸素灌流および再酸素化 を行い, 心機能と $\mathrm{Cx} 43$ のリン酸化状態との変化を検 討した。ささらに低酸素障害から心機能を保護すること が知られているカルシウムチャネルブロッカーである diltiazemを，それぞれ濃度を変化させながら前投与 および低酸素灌流中に投与し, 各群間において心機能 とCx43のリン酸化状態がどう変化するのか検討した。

灌流後の心筋細胞をリン酸化および脱リン酸化 $\mathrm{Cx} 43$ にそれぞれ特異的な抗体で免疫染色をすると，正 常心筋ではす寸付てのCx43はリン酸化されており介在板 に局在するが，低酸素にさらした心筋細胞では Cx 43 は脱リン酸化されてさらにその局在を細胞膜周囲に変 化させていた．この変化は組織切片内のすべての心筋 細胞で扔こるわけではなく，一部の心筋細胞内で結節 状に起こっていた。Cx43が脱りン酸化された心筋細 胞の組織切片内に打ける面積比を計算すると低酸素灌 流時間が長くなるにつれてこの領域は増加していた. また, 低酸素灌流のみの群では, 再酸素化を行った群 と比べてこの領域は増加していた。 心筋の酸素消費量 の指標であり，心機能を反映する\% PRP（PressureRate Product : 心拍数と左室発生圧の積) と脱リン 酸化 $\mathrm{Cx} 43$ の陽性領域はよい逆相関 $(\mathrm{y}=-0.99 \mathrm{x}+$

*日時 平成16年12月22日 (水)

於 順天堂大学 10 号館6階カンファレンスルーム

〔Jan. 19, 2005 原稿受領〕（Feb. 24, 2005 掲載決定）
$1.03 ； \mathrm{p}<0.01 ）$ を示した。つまり心筋が低酸素にさ らされるとCx43は脱りン酸化され，その局在を変化 させるが, 再酸素化により再りン酸化される。また再 酸素化後の心機能の回復と $\mathrm{Cx} 43$ のリン酸化状態はよ く相関することがわかった。

diltiazem を低酸素中に投与し同様の実験を行った. まず低酸素灌流中に濃度をそれぞれ $5 ， 20 \mu \mathrm{mol} / 1$ に 設定し, 低酸素灌流拉よび 30 分間再酸素化を行った. $5 \mu \mathrm{mol} / 1$ では再酸素化後の心機能, 脱リン酸化領域 の面積比とも有意差はなかったが, $20 \mu \mathrm{mol} / 1$ では 脱リン酸化領域の面積比は減少した。 \% PRPは両群間 で有意差がなかった。

次にdiltiazem を $1 \mu \mathrm{mol} / 1$, 低酸素前に投与した。 再酸素化後の心機能, 脱リン酸化領域の面積比とも有 意な改善を示した。これらのことから低濃度のdiltiazem 前投与は低酸素・再酸素化障害より心筋組織を 保護し, 同時に Cx43 の脱リン酸化変化も抑制するこ とが示唆された。

\section{生後初期の海馬で起こる細胞新生, 分化, 移動}

難波 隆志 ${ }^{1,2}$ 石 龍徳 ${ }^{1}$ 並木 秀男 2

1 解剖学第二 2 早稲田大学大学院

哺乳類の脳, 中枢神経系の神経細胞 (ニューロン) は胎仔期に新生することが知られている。しかし，例 外的に海馬顆粒細胞層では大部分のニューロンが生後 に新生し，その新生が成体期まで続く。ニューロンが 再生されないと考えられている中枢神経系において， このような生後のニューロン発生過程は, 再生医療を 考える上で非常に興味深い.われわれは生後初期海馬 において, どのような細胞が新生し, 移動し, そして どのような細胞へと分化するのかを解析するために以 下3つの実験を行った。

最初に新生細胞が海馬菌状回のどの領域に存在して いるかを調べた，新生細胞を標識するためにthymidineの類似物質である bromodeoxyuridine (BrdU) を生後5日目（P5）のrat腹腔内に投与した。 その後， 30 分，1日，3日，7日，14日に $4 \%$ パラフォルムアル 
デヒドで固定した. BrdU投与後 30 分では多数の新生. 細胞 ( BrdU陽性細胞) は顆粒細胞層内側に存在する hilus と呼ばれる領域に存在していた。一方，BrdU投 与後14 日目 (P19) にはBrdU陽性細胞（分裂後14 日目の細胞 ) は顆粒細胞層に存在していた。このこと はhilusで新生した細胞が顆粒細胞層へと移動したこ とを示している。

次にhilusに打いて分裂している細胞の性質とその 分化について解析を行った. BrdU 投与後 30 分では BrdU陽性細胞の約 $60 \%$ \%アストロサイトのマーカで

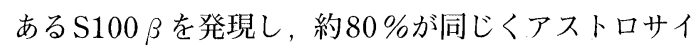
トのマーカであるGLASTを発現していた。一方，

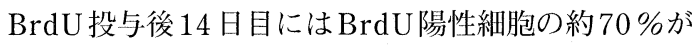
ニューロンのマーカであるHuを発現していた，以上 の結果より, 生後初期の海馬蒾状回ではアストロサイ 卜様細胞がhilusで分裂し，ニューロンへと分化して いる事が示唆された。

最後に, 緑色蛍光タンパク質EGFPを分裂細胞特異 的に強制発現させるレトロウィルスベクター ( RV ) を用いて以上の発生過程の形態学的解析を行った. P5 ratの海馬に直接 RVを注入し, 3 日後に固定した. RV 注入後 3 日目にはEGFP陽性細胞はhilus 全域に存在 し, $\mathrm{S} 100 \beta, \mathrm{Hu}$ ごちらか一方に陽性であった. 大部分 の $\mathrm{EGFP} / \mathrm{Hu}$ 二重陽性細胞は移動中のニューロンの 形態学的特徴を有していた.これらの EGFP $/ \mathrm{Hu}$ 二 重陽性細胞はしばしばhilusに位置する大型のニュー ロンとクラスタを形成していた。さらに，これらのク ラスタはEGFPに対する免疫電顕でも確認された。 以 上よりニューロンへの分化, 未熟ニューロンの成熟, 顆粒細胞層への移動の各過程に大型のニューロンとの 細胞間相互作用が重要である可能性が示唆された。

以上 3 つの結果から, 生後初期海馬に打いてはアス トロサイト様神経前駆細胞が顆粒細胞層へと移動しつ つニューロンへと分化することが判明した。 また，そ の発生過程に細胞間の相互作用が重要な役割を果たし ている可能性が示唆された。

前頭側頭型痴呆における神経細胞内封入体の超微形態 本井ゆみ子板谷 昌子 森 秀生 高梨 雅史 水野 美邦 脳神経内科 前頭側頭型痴呆症 Frontotemporal dementia (FTD) はAlzheimer病, Lewy 小体型痴呆の次に頻度の多い
変性痴呆性疾患である。臨床的にはAlzheimer病で早 期から記憶力障害が目立つのに対し，FTDでは早期 には記憶力が保たれ行動異常, 性格変化が目立つのが 特徵とされ 1994年に独立した疾患概念となった。組 織学的にはFTDの一つPick病において特異な嗜銀性 神経細胞内封入体が 1911年にAlzheimerにより報告 され，Pick小体と称され長く研究の対象とされてき た。更に, 分子遺伝学的に 1998 年に, タウ蛋白の遺 伝子異常により FTD を呈する家系（FTDP-17）が報 告されて以来, 注目される疾患となった。

タウ蛋白はalternative splicingにより6つのisoformから成る。それらはC末端の微小管結合ドメイ ンの数により 3 リピートタウ $(3 \mathrm{RT})$ と 4 リピートタウ （4RT）に分けられる. Pick病では3RTが沈着すると されていたが, 近年 $4 \mathrm{RT}$ 沈着の症例も報告されている.

本研究では異なる沈着タウアイソフォームを持つ FTD 例 2 例のPick球の超微形態を比較した.

FTD2 例の剖検時に側頭葉 $2 \mathrm{~cm}$ 四方を切り取り, $4 \%$ パラフォルムアルデヒドに 2 日間, $4{ }^{\circ} \mathrm{C} て ゙$ 固定後, ショ糖バッファーに保存した. $1 \mathrm{~mm}$ 角切片を $50 \mathrm{mMg}$ lycinePBSによりブロッキング後, エタノールにて脱 水, LR-Whiteに包埋して, 超薄切片を作成した.

免疫染色は抗りン酸化タウ抗体 (AT8) 拉よび抗4 リピートタウ特異的抗体 (RD4) を用いた。一次抗体 は一晚反応させ，二次抗体（金コロイド標識）は室温 で1時間反応させた。

沈着タウのisoformは凍結脳によるWestern blot にて決定した。

光顕的には $4 \mathrm{RT}$ 沈着のPick小体は3RT沈着のPick 小体に比較し大きい印象があった。超微形態的には 4RT 沈着のPick小体は主に100-190 nmの周期を持つ 捻じれ細管から構成され粗な平行配列を作り, 細胞小 器官を排除していた。一方 $3 R T$ 沈着のPick小体は主 に直細管から構成されランダムな配列で細管の隙間に 細胞小器官を有していた.

神経細胞内に存在する蛋白の生化学的違いが形態学 的相違を引き起こす可能性が in vivoで示された，神 経細胞内の蛋白沈着機構解明の手がかりとなるかもし れない. 